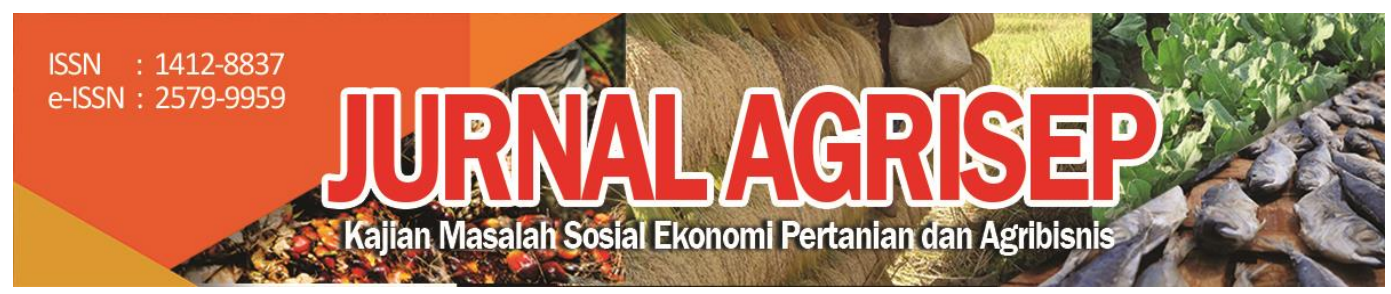

DOI: 10.31186/jagrisep.19.1.145-166

\title{
ANALISIS KELEMBAGAAN KELOMPOKTANI SISTEM INTEGRASI SAPI DAN KELAPA SAWIT (SISKA) DI KABUPATEN PELALAWAN
}

\author{
Institutional Analysis of Farmer Groups for the Cow-Oil Palm \\ Integrated System (SISKA) in Pelalawan District
}

\author{
Susy Edwina ${ }^{1)^{\bowtie}}$, Evy Maharani2), Yeni Kusumawaty3), Jumatri Yusri ${ }^{4)}$, \\ Yusmini ${ }^{5}$ \\ 1),2),3),4)Jurusan Agribisnis Fakultas Pertanian Universitas Riau \\ Email: susy.edwina@unri.ac.id
}

\begin{abstract}
Optimizing the area of oil palm plantations can be approached through the Cow and Palm Oil Integration System (SISKA), to increase efficiency and productivity through the integration of the plantation sub-sector with the livestock sub-sector. This study aimed to analyze the role of farmer groups and the institutional aspects of these groups in supporting the SISKA program in Pelalawan District. The approach used in this study was the institutional theory of Syahyuti. The role of farmer groups (as learning classes, production units and vehicles for collaboration) and institutional aspects of farmer groups (aspects of values, norms and behavior) were analyzed using Likert scale. The relationship between the roles and institutional aspects of the farmer groups was analyzed by Spearman Correlation test. The overall role of the farmer group is in the good category with a score of 3.49, most of the members (69.60\%) answered in the fairly good and good category. The overall institutional aspects based on values, norms and behavior in the SISKA farmer group are in the good category with a score of 4.05. Correlation on sub-variable values, norms and behavior towards the role of farmers as units of production is a strong direct correlation. This shows that values, norms and behavior in groups affect, encourage and enhance the role of groups as learning classes that support the level of knowledge of farmers and the role of farmer groups as production unit.
\end{abstract}

Keywords: institutional analysis, farmer group, perception, integrated system 


\begin{abstract}
ABSTRAK
Optimalisasi areal lahan perkebunan kelapa sawit dapat dilakukan melalui Sistem Integrasi Sapi dan Kelapa Sawit (SISKA), dalam upaya peningkatan efisiensi dan produktivitas melalui keterpaduan sub sektor perkebunan dengan sub sektor peternakan. Penelitian ini bertujuan untuk menganalisis peran kelompoktani dan aspek kelembagaan kelompok dalam mendukung program SISKA di Kabupaten Pelalawan. Pendekatan yang digunakan dalam penelitian ini adalah teori kelembagaan dari Syahyuti. Peran kelompoktani (sebagai kelas belajar, unit produksi dan wahana kerjasama) serta aspek kelembagaan kelompoktani (aspek nilai, norma dan perilaku) dianalisis dengan skala likert. Hubungan antara peran dan aspek kelembagaan kelompoktani dianalisis dengan uji Korelasi Spearman. Peran kelompoktani secara keseluruhan berada pada kategori baik dengan skor 3,49, sebagian besar anggota (69,60\%) menjawab pada kategori cukup baik dan baik. Aspek kelembagaan berdasarkan nilai, norma dan perilaku pada kelompok tani SISKA secara keseluruhan termasuk kategori baik dengan skor 4,05. Korelasi pada sub variabel nilai, norma dan perilaku terhadap peran kelompoktani sebagai unit produksi adalah korelasi searah kuat. Hal ini menunjukkan bahwa nilai, norma dan perilaku dalam kelompoktani mempengaruhi, mendorong dan meningkatkan peran kelompok sebagai kelas belajar yang mendukung tingkat pengetahuan petani dan peran kelompoktani sebagai unit produksi.
\end{abstract}

Kata kunci: analisis kelembagaan, kelompoktani, persepsi, sistem integrasi

\title{
PENDAHULUAN
}

Sistem integrasi sapi dan kelapa sawit merupakan perpaduan antara manajemen perkebunan kelapa sawit dengan ternak sapi. Menurut Ilham (2011) terintegrasinya usaha sapi potong dan perkebunan sawit dapat mengurangi biaya lahan dan pakan serta meningkatkan kapasitas tampung sehingga skala usaha menjadi besar dan makin efisien.

Kelompoktani merupakan kelembagaan ditingkat petani yang dibentuk untuk mengorganisir petani dalam aktivitas usahatani, merupakan kumpulan petani yang dibentuk atas dasar kepentingan, kesamaan kondisi lingkungan dan keakraban untuk meningkatkan dan mengembangkan usaha anggota. Kelompoktani dianggap organisasi yang efektif untuk memberdayakan petani, peningkatan produktivitas, pendapatan dan kesejahteraan melalui bantuan dan fasilitas dari pemerintah.

Perkembangan jumlah kelompoktani yang mendapat program SISKA sejak tahun 2010 di Kabupaten Pelalawan cukup signifikan, terdapat 22 kelompoktani yang mendapat bantuan dan fasilitas dari pemerintah, namun sebagian dari kelompok tersebut saat ini tidak lagi menjalankan aktivitas yang berkaitan dengan program SISKA. Menurut Syahyuti (2003) pengembangan kelembagaan banyak mengalami ketidaktepatan dan kekeliruan, diantaranya 
kelembagaan dibentuk untuk tujuan distribusi bantuan, pembinaan cenderung individual, pengembangan kelembagaan menggunakan jalur struktural dan lemah dari aspek kultural.

Permasalahan pokok yang akan dijawab dalam penelitian ini adalah mengapa adopsi inovasi pada kelompoktani yang mendapat bantuan program SISKA tidak berlanjut? Dalam rangka mendukung program SISKA berbagai upaya perlu dilakukan mengingat peran kelompoktani sebagai kelas belajar, unit produksi dan wadah kerjasama. Beberapa kajian menunjukkan pembentukan kelompoktani tidak dilakukan secara partisipatif, sehingga tidak dapat mengakomodasi potensi dan kepentingan petani yang seharusnya menjadi modal untuk melakukan aksi kolektifnya (Hermanto dan Swastika 2011).

Penerapan SISKA sangat tergantung pada kelembagaan kelompoktani, dibutuhkan perhatian terhadap aspek kelembagaan dilihat dari nilai, norma dan perilaku petani dalam kelompok sebagai kunci keberhasilan pengembangan SISKA. Penerapan SISKA di Kabupaten Pelalawan masih berjalan hingga sekarang, namun terdapat penurunan jumlah kelompok yang masih menerapkan. Berdasarkan data Dinas Peternakan Kabupaten Pelalawan (2015), terdapat lebih dari 15 kelompok yang menerima bantuan, hingga tahun 2016 tinggal 11 kelompok yang masih aktif.

Penelitian ini bertujuan untuk: mengetahui persepsi petani terhadap peran kelompoktani sebagai kelas belajar, unit produksi dan wahana kerjasama; mengetahui persepsi petani terhadap aspek kelembagaan kelompoktani; dan menganalisis hubungan antara peran kelompoktani dan aspek kelembagaan dalam penerapan SISKA di Kabupaten Pelalawan.

\section{METODE PENELITIAN}

Penelitian ini dilakukan di Kabupaten Pelalawan, Provinsi Riau yang diawali bulan Mei 2016. Pemilihan lokasi dilakukan secara sengaja di Kecamatan Pangkalan Lesung dan Kecamatan Kerumutan Kabupaten Pelalawan sebagai daerah dengan kelompoktani penerima dana SISKA yang masih melaksanakan aktivitas dalam kelompok.

Metode yang digunakan dalam penelitian ini adalah metode survei dengan pengambilan sampel petani pada 11 kelompoktani yang masih melaksanakan SISKA dan menerima bantuan sapi dari Dinas Peternakan Kabupaten Pelalawan dan pemeliharaan sapi terintegrasi dengan perkebunan kelapa sawit jumlah total sebanyak 125 orang. Metode pengumpulan data melalui pengamatan langsung pada aktivitas kelompok; wawancara terstruktur menggunakan kuisioner kepada petani dan penyuluh. Jenis data yang dikumpulkan berupa data primer dan sekunder.

Menurut Sugiyono (2017) skala Likert digunakan sebagai referensi dalam pemprosesan data dari kuesioner. Skala Likert adalah skala yang berdasarkan 
atas jumlah sikap dari responden dalam merespon pertanyaan yang berkaitan dengan indikator-indikator suatu konsep atau faktor yang sedang diukur. Skala Likert digunakan untuk mengukur sikap, pendapat dan persepsi seseorang atau sekelompok tentang kejadian atau gejala sosial (Akdon dan Hadi 2005). Skor nilai jawaban terhadap penilaian persepsi petani disajikan pada Tabel 1.

Tabel 1. Skor Penilaian Persepsi Petani SISKA

\begin{tabular}{lcc}
\hline Kategori & Skala & Skor \\
\hline Tidak Baik (TB) & 1 & $1,00-1,79$ \\
Kurang Baik & 2 & $1,80-2,59$ \\
(KB) & 3 & $2,60-3,39$ \\
Cukup Baik (CK) & 4 & $3,40-4,19$ \\
Baik (B) & 5 & $4,00-5,00$ \\
Sangat Baik (SB) & & \\
\hline
\end{tabular}

Selanjutnya untuk mengetahui hubungan peran kelompoktani dengan aspek kelembagaan (nilai, norma dan perilaku) dilakukan analisis Spearman karena menurut (Harjoyo, 2009) kuesioner dalam bentuk skala Likert menghasilkan data ordinal, maka uji validitas dilakukan dengan menggunakan pendekatan stastistik korelasi Rank Spearman (Spearman Rho) untuk tiap-tiap butir pernyataan. Menurut Rintar (2011) analisis Spearman ini dilakukan untuk menganalisis apakah data sampel memiliki bukti bahwa terdapat keterkaitan antara variabel-variabel yang diteliti. Korelasi Spearman digunakan pada data yang berskala ordinal semuanya atau sebagian data adalah ordinal. Sebelum dilakukan pengolahan data, data yang akan dianalisis perlu disusun dalam bentuk ranking, sehingga korelasi spearman merupakan alat uji statistik yang digunakan untuk menguji hipotesis asosiatif dua variabel bila datanya berskala ordinal (ranking). Rumus uji korelasi rank spearman adalah sebagai berikut :

$$
r_{s}=\frac{6 \Sigma_{i}^{n}-1 d_{i}^{2}}{n\left(n^{2}-1\right)}
$$

Keterangan :

$\mathrm{r}_{\mathrm{s}} \quad$ : Koefisien korelasi rank spearman.

di : perbedaan (selisih) antara kedua rangking ( $\mathrm{X}$ dan $\mathrm{Y}$ )

n : jumlah sampel

Penelitian sebelumnya Guntoro dan Sulastri (2014) menggunakan analisis korelasi rank Spearman untuk melihat hubungan antara karakteristik peternak dengan persepsi peternak terhadap peran petugas penyuluh. Pada penelitian ini, variabel independent $(X)$ adalah tujuan kelompoktani $(X)$ sedangkan variabel dependent $(\mathrm{Y})$ adalah persepsi anggota terhadap peran kelompoktani 
sebagai kelas belajar, unit produksi, dan wahana kerjasama. Kriteria pengambilan keputusan pengujian signifikan adalah jika $\mathrm{P}<0,05$ maka variabel tersebut memiliki hubungan yang signifikan dengan tingkat keyakinan 0,95 dan $\mathrm{P}>0,05$ maka variabel tersebut memiliki hubungan yang tidak signifikan. Adapun nilai korelasi berkisar antara -1 hingga +1 . Nilai yang mendekati -1 atau +1 menyatakan hubungan makin kuat, sedangkan nilai yang mendekati angka 0 dikatakan memiliki hubungan lemah.

\section{HASIL DAN PEMBAHASAN}

\section{Peran Kelompoktani dalam Mendukung Keberhasilan Program SISKA}

Menurut Kartasapoetra (1994) terdapat 3 peran utama dari kelompoktani yaitu berperan sebagai kelas belajar, unit produksi dan sebagai wahana kerjasama.

\section{Persepsi Anggota terhadap Peran Kelompoktani sebagai Kelas Belajar}

Berdasarkan Peraturan Menteri Pertanian Nomor: 273/KPTS/OT.160/4/ 2007 Tahun 2007 kelompok tani memiliki fungsi sebagai kelas belajar guna meningkatkan pengetahuan, ketrampilan, dan sikap (PKS) sehingga tumbuh kemandirian, meningkatnya produktivitas, dengan harapan mencapai kesejahteraan. Persepsi anggota terhadap peran kelompoktani dapat dilihat pada Tabel 2.

\section{Tabel 2. Persepsi Anggota Terhadap Peran Kelompoktani}

\begin{tabular}{|c|c|c|c|}
\hline No. & Sub Variabel & Skor & Kategori \\
\hline \multirow[t]{7}{*}{1} & Kelas Belajar & 3,34 & Cukup Baik \\
\hline & $\begin{array}{l}\text { a. Hubungan dan kerjasama dengan } \\
\text { instansi }\end{array}$ & 3,70 & Baik \\
\hline & $\begin{array}{l}\text { b. Hubungan dan kerjasama dengan } \\
\text { sesama anggota }\end{array}$ & 3,66 & Baik \\
\hline & c. Iklim/suasana belajar di kelompok & 4,16 & Baik \\
\hline & d. Ketersediaan sarana belajar & 2,94 & Cukup Baik \\
\hline & $\begin{array}{l}\text { e. Frekuensi pertemuan kelompok dalam } \\
\text { mengatasi masalah }\end{array}$ & 3,42 & Baik \\
\hline & $\begin{array}{l}\text { f. Penyusunan rencana } \\
\text { kelompok(AD/ART) }\end{array}$ & 2,15 & Kurang Baik \\
\hline \multirow[t]{4}{*}{2} & Unit Produksi & 3,67 & Baik \\
\hline & a. Pola usaha tani SISKA menguntungkan & 3,85 & Baik \\
\hline & b. Kelompoktani menyediakan saprodi & 3,60 & Baik \\
\hline & $\begin{array}{l}\text { a. Aktivitas produktif dalam menerapkan } \\
\text { SISKA }\end{array}$ & 3,57 & Baik \\
\hline
\end{tabular}


Tabel 2. Persepsi Anggota Terhadap Peran Kelompoktani (lanjutan)

\begin{tabular}{llrl}
\hline No. & \multicolumn{1}{c}{ Sub Variabel } & Skor & Kategori \\
\hline 3 & Wahana Kerjasama & 3,45 & Baik \\
& $\begin{array}{l}\text { a. Tingkat kepercayaan dengan sesama } \\
\text { anggota }\end{array}$ & 4,66 & Sangat Baik \\
& 3,14 & Cukup Baik \\
b. Pembagian tugas dikelompok & 2,54 & Kurang Baik \\
& $\begin{array}{l}\text { c. Frekuensi pengelolaan dan pemasaran } \\
\text { hasil dilakukan bersama kelompok }\end{array}$ & & \\
\hline \multicolumn{2}{r}{ Rata-rata } & 3,49 & Baik \\
\hline
\end{tabular}

Peran kelompoktani sebagai kelas belajar secara keseluruhan berada pada kategori cukup baik dengan skor 3,34, sebagian besar anggota $(69,60 \%)$ menjawab pada kategori cukup baik dan baik. Hubungan dan kerjasama sesama anggota dan iklim/suasana belajar tergolong baik, namun ketersediaan sarana belajar tergolong kategori cukup baik,seperti tempat hanya terdapat pada sebagian kecil kelompok, dari jawaban 37,60\% anggota yang menjawab tidak baik dan kurang baik. Sedangkan peran dalam penyusunan rencana kelompok kurang baik,peran kelompok sebagai kelas belajar dalam penyusunan ADRT sangat rendah dari jawaban 53,60\% tergolong tidak baik.

\section{Hubungan dan Kerjasama dengan Instansi}

Berdasarkan Tabel 2. peran kelompok sebagai kelas belajar, dalam menjalin hubungan dan kerjasama dengan instansi pembina dan sesama anggota memiliki skor 3,70, berada pada kategori "baik", dilihat dari frekuensi komunikasi dan kunjungan instansi pembina rata-rata 2 kali dalam sebulan, seperti penyuluh dari dinas peternakan. Peran penyuluh dalam mengatasi masalah kelompok seperti kendala dalam pengadaan pakan, pemeliharaan sapi, jika sapi mengalami sakit, gangguan sulit makan, proses perkawinan atau inseminasi buatan (IB) dan jika sapi akan beranak. Menurut Wastika et al. (2014) faktor yang berpengaruh secara nyata terhadap peran kelompoktani adalah adalah sikap dan peran penyuluh.

\section{Hubungan dan Kerjasama dengan Anggota}

Rata-rata skor untuk melihat intensitas hubungan dan kerjasama sesama anggota kelompok 3.66, tergolong kategori baik, yaitu rata-rata 2 kali sebulan pada saat arisan kelompok dan kerjasama dalam pemeliharaan ternak dikandang. Kerjasama yang dilakukan pada saat arisan yaitu membahas mengenai seluruh anggaran pemasukan dan pengeluaran kelompok, sedangkan kerjasama ketika di kandang yaitu membahas tentang perkembangan sapi dan rencana kedepan untuk pemeliharaan sapi. Menurut 
Ramadoan et al. (2013) faktor pendorong yang dianggap mampu meningkatkan partisipasi anggota pada kegiatan di kelompok adalah dorongan dari dalam diri sendiri dan keikutsertaan sebagai anggota kelompok.

Sebagian kelompok jarang berkumpul karena anggota memiliki kesibukan dalam pekerjaan utama sebagai karyawan pada perusahaan perkebunan serta ketidaksesuaian waktu luang karyawan dengan kegiatan pemeliharaan ternak. Disamping itu ada juga kelompok yang menyerahkan pemeliharaan ternak kepada 1 orang anggota yang dipercaya, sehingga tidak terjalin kerjasama. Hasil penelitian Ramadoan et al. (2013) menunjukkan rendahnya tingkat kesadaran dan kepedulian masyarakat dapat dipengaruhi oleh faktor internal (seperti kurangnya pengetahuan, pendidikan dan kemampuan), serta faktor eksternal (seperti kurangnya penyuluhan, pelatihan, sarana prasarana, media masa sebagai sumber informasi), dan faktor pembelajaran yang belum memadai.

\section{Iklim/Suasana Belajar dikelompok}

Sebagian besar anggota kelompok $(85,50 \%)$ menjawab pada kategori baik dan sangat baik terhadap iklim/suasana belajar dalam proses pembelajaran yang dilakukan instansi pembina, terlihat dari skor rata-rata 4,16 berada pada kategori baik. Suasana belajar dikelompok yang diterapkan instansi pembina sangat menyenangkan, anggota kelompok mendapatkan tambahan ilmu, pengalaman, serta pendampingan dalam mengatasi permasalahan sapi dan dan bisa membangun relasi yang baik dengan instansi. Menurut Penyuluh Peternakan Lapangan di Kecamatan Kerumutan, sebagai pendamping petani, penyuluh harus memberikan kesan yang menyenangkan ketika berhadapan dengan petani.

\section{Ketersediaan Sarana Belajar}

Ketersediaan sarana belajar di kelompok memiliki skor rata-rata 2,94, berada pada kategori "cukup baik", menunjukkan rata-rata ada 3 sarana dimiliki kelompok, seperti meja/kursi, buku panduan beternak dan papan informasi perkembangan ternak. Sebagian kelompok memiliki sarana lengkap, berupa ruang rapat/pertemuan, meja dan kursi, papan tulis, papan informasi ternak, buku-buku penunjang, poster/gambar tentang pemeliharaan sapi,yang membantu meningkatkan motivasi anggota dalam melaksanakan program SISKA karena merupakan kelompok percontohan yang mendapat fasilitas dari pemerintah daerah maupun pusat.

Ketersediaan sarana belajar pada sebagian kelompok yang menerapkan pemeliharaan sapi secara individu tidak tersedia. Pemeliharaan ternak dengan sistem kandang individu menjadi pertimbangan dinas terkait belum memberikan bantuan sarana pendukung lainnya. 


\section{Frekuensi pertemuan kelompok dalam mengatasi masalah}

Frekuensi pertemuan kelompok dalam mengatasi masalah dengan ratarata skor 3,42, termasuk kategori baik, sebanyak $76,80 \%$ anggota menjawab pada kategori cukup baik dan baik, menunjukkan rata-rata pertemuan untuk mengatasi masalah dalam kelompok 2 kali dalam sebulan, biasanya disesuaikan dengan agenda pertemuan rutin kelompok setiap bulan. Masalah yang sering terjadi di kelompok seperti kecemburuan sosial antar anggota, ketika salah satu anggota tidak melaksanakan kewajiban, masalah pakan, ternak sakit atau mati dan lainnya.

Pertemuan bulanan pada beberapa kelompok lebih dari 2 kali, didukung ketersediaan sarana, tempat rapat dan kekompakkan anggota dalam menjalankan tugas masing-masing meskipun kadangkala terdapat perbedaan pendapat, tentang masalah pengguliran ternak sapi. Rapat bulanan dilakukan setiap tanggal 10 dirumah ketua kelompok, diluar waktu tersebut anggota sering mengadakan pertemuan, setiap anggota antusias dengan perkembangan kelompok, karena merasa mempunyai hak atas ternak dan menjadi bagian dari kelompok. Menurut Wastika et al. (2013) wujud dari kegiatan kelompok tani bisa dicerminkan adanya pertemuan anggota kelompok secara rutin dan kegiatan gotong royong.

Sebagian kelompok melakukan pertemuan 1 kali sebulan, karena kepedulian anggota terhadap kelompok menurun setelah penyakit yang menyerang 4 ekor sapi yang berujung dengan kematian. Disamping itu terdapat 1 kelompok tidak melakukan pertemuan, karena merasa tidak menjadi anggota kelompok lagi, sehingga menerima apapun keputusan yang diambil ketua.

\section{Penyusunan rencana kelompok (ADRT)}

Peran kelompok dalam penyusunan ADRT memiliki skor rata-rata 2,15, termasuk kategori kurang baik, menunjukkan kelompok pernah menyusun rencana $\mathrm{AD} / \mathrm{ART}$ rata-rata $1 \mathrm{kali}$, karena pengetahuan kelompok tentang penyusunan rencana usaha dan permodalan rendah serta terbatasnya peran dari pihak pendamping. Peran pendamping diperlukan terutama dalam menyusun AD/ART yang dilakukan oleh kelompoktani. Meskipun ada kelompok yang tidak pernah menyusun $\mathrm{AD} / \mathrm{ART}$ ), mengingat yang bekerja dan bertanggung jawab dalam menjalankan tugas kelompok hanya ketua, anggota tidak pernah terlibat. Mayoritas kelompok sudah memiliki rencana, jangka pendek maupun jangka panjang, seperti rencana pengembangan usaha melalui perbanyakan jumlah sapi yang akan datang, seiring rencana perluasan area kandang. Rencana jangka panjang sepertikepemilikan mesin pencacah pelepah kelapa sawit dan mesin pengolah kompos yang lebih efisien sehingga mampu memenuhi permintaan anggota kelompok dan diluar anggota. Namun demikian rencana usaha belum tertuang dalam rencana tahunan kelompok 
yang tersusun secara sistematis sebagai pedoman bagi kelompok dalam pengambilan keputusan.

\section{Persepsi Anggota Terhadap Peran Kelompok Tani sebagai Unit Produksi}

Kartasapoetra (1994) menyatakan bahwa usahatani yang dilaksanakan oleh masing-masing anggota kelompoktani, secara keseluruhan harus dipandang sebagai satu kesatuan usaha yang dapat dikembangkan untuk mencapai skala ekonomi, baik dipandang dari segi kuantitas, kualitas maupun kontinuitas.

\section{Usaha Tani SISKA Menguntungkan}

Peran kelompok sebagai unit produksi memiliki skor rata-rata 3,67, berada pada kategori "baik", memberikan makna bahwa usahatani dengan pola SISKA menguntungkan. Menurut petani, SISKA memberikan banyak manfaat, diantaranya membantu anggota dalam kepemilikan aset ternak, yang mengalami peningkatan dari segi jumlah serta peluang pengembangan usaha lain seperti kegiatan pengolahan produksi limbah kotoran ternak untuk dijadikan pupuk organik. Anggota merasakan manfaat dari kegiatan usahatani yang dikelola secara terintegrasi antara kelapa sawit dan sapi menguntungkan, dilihat dari peningkatan jumlah sapi yang dimiliki kelompok, hasil penjualan pupuk organik padat dan cair yang selalu mengalami kemajuan demikian juga dengan hasil penjualan sapi.

\section{Ketersediaan Saprodi}

Skor rata-rata untuk mengetahui peran kelompok tani sebagai unit produksi dilihat dari penyediaan sarana produksi yaitu 3,60, tergolong kategori baik, dilihat dari 48,30\% anggota memberikan jawaban yang termasuk kategori baik dan sangat baik. Kondisi ini menunjukkan rata-rata kelompok menyediakan 3 sarana produksi untuk membantu penerapan SISKA, yang terdiri dari mesin choopper, pengadaan pelepah kelapa sawit, bungkil, solid, pupuk cair (limbah cair) dan pupuk kandang (limbah padat).

\section{Aktivitas Produktif lain}

Peran kelompoktani sebagai unit produksi dalam melakukan aktivitas produktif lain memiliki skor rata-rata 3,57, termasuk kategori baik berdasarkan jawaban $48,30 \%$ anggota yang tergolong baik dan sangat baik. Hal ini menggambarkan dalam penerapan SISKA pada umumnya kelompok melakukan 3 aktivitas produktif, antara lain usaha produksi pupuk kompos, pupuk organik cair, biogas dan pakan konsentrat. Aktivitas produksi pada kelompok yang termasuk pada kategori sangat baik,seperti usaha produksi 
pakan konsentrat, pupuk kompos, pupuk cair, usaha penjualan sapi dan sudah memanfaatkan biogas sebagai energi pengganti.

Kelompok yang berada pada kategori "cukup baik", melakukan aktivitas produktif rata-rata 2 kegiatan saja, yaitu usaha produksi pupuk kandang dan pupuk cair organik. Kondisi ini dipengaruhi dalam pemeliharaan ternak tidak dalam kandang koloni atau kandang bersama melainkan ternak dipelihara secara perorangan.

\section{Persepsi Anggota Terhadap Peran Kelompok sebagai Wahana Kerjasama}

Kelompoktani merupakan tempat untuk memperkuat kerjasama diantara sesama petani dalam kelompok dan antar kelompok serta dengan pihak lain. Melalui kerjasama ini diharapkan usahataninya akan lebih efisien serta lebih mampu menghadapi ancaman, tantangan, hambatan dan gangguan.

Peran kelompoktani sebagai wahana kerjasama memiliki skor 3,45 termasuk kategori baik, petani saling mengenal dan percaya dengan sesama anggota, mayoritas petani transmigrasi berasal dari desa yang sama, dikarenakan adanya klik atau kecocokan yang timbul dari ikatan pertemanan, persaudaraan dan latar belakang kesukuan. Pembagian tugas dalam kelompok tergolong cukup baik, sebagian kelompok menerapkan pembagian tugas sesuai struktur organisasi namun demikian tidak semua kelompok menerapkan pembagian tugas, seperti kelompok yang anggotanya tidak aktif lagi sehingga semua tugas dikerjakan ketua. Frekuensi pengelolaan dan pemasaran hasil yang dilakukan bersama kelompok tergolong kurang baik dengan skor 2,54 karena produksi pupuk kandang, pupuk organik cair lebih diutamakan untuk memenuhi permintaan anggota.

\section{Aspek Kelembagaan Kelompoktani Sistem Integrasi Dari Nilai, Norma dan Perilaku}

Syahyuti (2003) mengemukakan bahwa aspek kelembagaan terdiri dari 3 pilar, yaitu nilai, norma dan perilaku. Lebih lanjut skor aspek kelembagaan akan diuraikan sesuai dengan variabel yang menggambarkan aspek kelembagaan pada Tabel 3. 
Tabel 3 Persepsi Anggota Terhadap Aspek Kelembagaan

\begin{tabular}{|c|c|c|}
\hline Sub Variabel & Skor & Kategori \\
\hline \multicolumn{3}{|l|}{1 Nilai } \\
\hline $\begin{array}{l}\text { a. Sistem tata nilai yang dianut oleh anggota } \\
\text { kelompok }\end{array}$ & 4,28 & Sangat Baik \\
\hline b. Nilai-nilai yang diterapkan dalam bekerja & 3,86 & Baik \\
\hline c. Persepsi terhadap waktu & 3,99 & Baik \\
\hline d. Sikap dasar tentang hubungan manusia & 4,77 & Sangat Baik \\
\hline dengan sesama & 4,57 & Sangat Baik \\
\hline e. Nilai yang berkembang & 4,19 & Baik \\
\hline \multicolumn{3}{|l|}{2 Norma } \\
\hline a. Sistem norma yang diterapkan secara & 4,13 & Baik \\
\hline umum & 4,47 & Sangat Baik \\
\hline b. Struktur norma yang berjalan & 3,13 & Cukup Baik \\
\hline c. Persepsi terhadap kedudukan seseorang & 4,43 & Sangat Baik \\
\hline $\begin{array}{l}\text { d. Pengaruh norma terhadap aktivitas dan } \\
\text { pencapaian tujuan kelompok }\end{array}$ & 4,25 & Sangat Baik \\
\hline $\begin{array}{l}\text { e. Pengaruh sentimen kekerabatan, } \\
\text { pertemanan terhadap kelompok }\end{array}$ & 4,62 & Sangat Baik \\
\hline $\begin{array}{l}\text { f. Persepsi terhadapterhadap sistem reward } \\
\text { dan punishment }\end{array}$ & 3,90 & Baik \\
\hline \multicolumn{3}{|l|}{3 Perilaku } \\
\hline a. Iklim utama dalam kelompok & 3,75 & Baik \\
\hline $\begin{array}{l}\text { b. Faktor yang mempengaruhi perilaku posisi } \\
\text { dalam kelompok }\end{array}$ & 4,43 & Sangat Baik \\
\hline $\begin{array}{l}\text { c. Sumber kekuatan yang menentukan } \\
\text { perilaku kerja }\end{array}$ & 3,63 & Baik \\
\hline $\begin{array}{l}\text { d. Syarat menduduki jabatan pimpinan (visi, } \\
\text { sikap komunikatif, keteladanan, alturuistik, } \\
\text { rasionalitas, sikap demokratis) }\end{array}$ & 3,66 & Baik \\
\hline $\begin{array}{l}\text { e. Kompetensi utama dalam menduduki } \\
\text { jabatan (pendidikan, keterampilan, }\end{array}$ & 3,72 & Baik \\
\hline $\begin{array}{l}\text { kematangan emosional, kepedulian } \\
\text { terhadap etika dan moral }\end{array}$ & 3,93 & Baik \\
\hline $\begin{array}{l}\text { f. Hal yang dimiliki bersama (nasib, } \\
\text { kepentingan, tujuan, idiologi) }\end{array}$ & 3,14 & Cukup Baik \\
\hline Rata-rata & 4,05 & Baik \\
\hline
\end{tabular}

\section{Persepsi Terhadap Nilai yang Dianut Kelompoktani}

Menurut Syahyuti (2003) nilai merupakan konsepsi abstrak didalam diri manusia mengenai apa yang dianggap baik dan apa yang dianggap buruk. 
Nilai mencerminkan suatu kualitas preferensi dalam tindakan, memberi perasaan identitas, dan menentukan seperangkat tujuan yang hendak dicapai oleh suatu kelompok. Persepsi petani terhadap nilai yang dianut dalam kelompok dilihat berdasarkan: sistem tata nilai yang dianut oleh anggota kelompok, nilai-nilai yang diterapkan dalam bekerja, persepsi terhadap waktu, sikap dasar tentang hubungan manusia dengan sesama dan nilai-nilai yang berkembang.

\section{Sistem tata nilai yang dianut oleh anggota kelompok}

Sistem tata nilai yang dianut oleh anggota kelompoktani bersumber dari nilai kearifan setempat, nilai agama maupun social, dengan rata-rata skor 3,79. Tata nilai yang bersumber dari kearifan setempat terlihat dari tidak adanya kelompok atau masyarakat yang memelihara ternak kerbau karena dianggap tabu. Nilai yang diterapkan berlandaskan agama, dalam bentuk kejujuran dan keterbukaan dalam seluruh kegiatan kelompok, baik berupa bantuan yang diterima dari instansi pembina maupun pengeluaran untuk biaya operasional. Sementara itu nilai social terlihat dari kebersamaan dan kekompakan yang terjalin melalui sikap toleransi dalam pelaksanaan kegiatan dalam kelompoktani, misalnya, ketika salah satu anggota berhalangan melaksanakan kewajiban, maka anggota yang lain sukarela untuk menggantikan tanggungjawab tersebut.

\section{Nilai-nilai yang diterapkan dalam bekerja}

Nilai yang diterapkan dalam bekerja dengan skor 3,99 termasuk kategori baik, berdasarkan keyakinan "bekerja sebagai karya", bekerja dalam kelompok tidak bertujuan untuk pemenuhan kebutuhan hidup sehari-hari atau pemenuhan konsumsi, namun merupakan upaya untuk melakukan kegiatan produktif beternak sapi yang dapat dinikmati pada masa yang akan datang. Kegiatan SISKA di kelompok merupakan pekerjaan sampingan yang hasilnya diharapkan sebagai tabungan untuk membiayai pendidikan anak maupun membeli asset berupa lahan kebun kelapa sawit. Bekerja sebagai karya tercermin dari kemampuan kelompok mengolah kotoran dan urin sapi menjadi pupuk organic, dalam bentuk kecintaan terhadap alam, mendaur ulang limbah pelepah kelapa sawit menjadi produk yang bernilai ekonomis.

\section{Persepsi terhadap waktu}

Persepsi petani terhadap waktu dengan skor 4,77 termasuk Kategori "sangat baik" yaitu memiliki orientasi ke masa depan, dengan pola pikir mengarah kepada rencana jangka panjang, seperti keinginan untuk masa depan anak melalui pendidikan, melakukan usaha yang memiliki jaminan pada masa tua, didukung upaya membeli aset berupa lahan perkebunan dan ternak. Petani 
memiliki keyakinan usaha SISKA menghasilkan pendapatan dari ternak yang dapat menjadi tabungan dimasa depan.

\section{Sikap dasar tentang hubungan manusia dengan sesama}

Sikap dasar tentang hubungan manusia dengan sesama yang berkembang ialah "horizontal", dengan skor 4,57. Hubungan terjalin sesama anggota yang saling membutuhkan, bekerjasama, saling menghormati dan menghargai baik dalam kelompok maupun dimasyarakat merupakan jalan untuk mencapai tujuan kelompok. Menurut Trisnanto et al. (2017) mekanisme membangun solidaritas dalam Gapoktan melalui penguatan rasa saling percaya pada segenap unsur (pengurus dan anggota) dan penyatuan kesamaan norma identitas dan nilai kerjasama serta keterbukaan dalam jejaring yang sinergis.

Sebagian kelompok memandang hubungan yang baik itu bersifat vertikal, ditunjukan melalui sikap terhadap Allah sebagai pencipta, berupa pengakuan atas kenyataan manusia begitu kecil dan rendah dihadapan tuhan, mengakui keterbatasan dan ketidakberdayaan. Anggota menyadari semua yang terjadi adalah ketentuan-Nya, hubungan manusia dengan tuhannya akan menentukan hubungan manusia dengan sesama manusia. Rasa saling menghargai, saling peduli dan toleransi antar anggota kelompok melalui musyawarah adalah sifatsifat yang diajarkan oleh agama dalam berhubungan dan berinteraksi dengan sesama makhluk tuhan.

\section{Nilai-nilai yang berkembang}

Nilai-nilai yang berkembang adalah "menjunjung tinggi keselarasan", dengan skor 4,19. Aktivitas usaha yang dilakukan mengarah kepada pencapaian tujuan kelompok, yaitu menjaga keselarasan usaha produktif dan kelestarian alam melalui pengolahan pakan ternak dari limbah pelepah kelapa sawit, pengolahan pupuk organik dari kotoran dan urin sapi melalui proses fermentasi, pengganti pupuk an organik yang ramah lingkungan sehingga kesuburan tanah terjaga dan tidak mencemari lingkungan.

Demikian juga aturan yang dibuat untuk memberikan arah dan batasanbatasan bagi setiap anggota baik ketua, sekretaris, bendahara dan pengurus lainnya dalam bertindak. Sebagian kelompok menerapkan manajemen yang berorientasi keuntungan (bisnis) sehingga ada kelompok hanya menggunakan tenaga kerja luar kelompok yang berpengalaman dalam pemeliharaan ternak. Sementara itu ada kelompok yang menyerahkan pengelolaan kepada beberapa orang anggota saja, sehingga pembagian hasil antara anggota tergantung partisipasi dalam kelompok.

\section{Persepsi Terhadap Norma yang Dianut Kelompoktani}

Norma merupakan aturan sosial, patokan berperilaku yang pantas atau tingkah laku rata-rata yang diabstraksikan. 


\section{Sistem norma yang diterapkan secara umum.}

Skor rata-rata untuk indikator sistem norma adalah 4,47, termasuk kategori sangat baik, yaitu sistem norma yang diterapkan secara umum berlandaskan kearifan setempat dan agama. Aturan yang dibuat pada beberapa kelompok sudah tertuang pada AD/ART, mengikat semua anggota kelompok dan berlaku umum, tidak ada perbedaan atau keistimewaan untuk ketua dan pengurus inti kelompok.

Contoh norma yang diterapkan berdasarkan kearifan setempat, diantaranya larangan sapi memasuki kebun atau ladang milik orang lain, jika sapi-sapi tersebut merusak dan memakan tanaman milik warga, maka pemilik sapi wajib membayar ganti rugi; aturan wajib ronda malam secara bergantian; aturan dalam iuran wajib untuk biaya operasional kegiatan kelompok; aturan tata cara pemeliharaan ternak (secara koloni atau individu); penetapan waktu dan tempat untuk rapat bulanan, kebijakan dan sanksi jika anggota kelompok tidak datang rapat di kelompok 3 kali berturut-turut, aturan tentang syarat masuk serta keluar dari kelompok. Sebagian kelompok menerapkan sistem norma yang berlandaskan agama sebagai dasar hukum tertinggi yang mengatur segala segi kehidupan manusia, sehingga aturan yang disepakati kelompok sangat erat dengan aturan agama islam, karena semua anggota beragama islam.

\section{Struktur norma yang berjalan}

Struktur norma yang berjalan, memiliki skor 3,13, termasuk kategori cukup baik, menunjukkan norma yang ditetapkan dan diterapkan oleh kelompok meliputi beberapa aturan baku atau mutlak yang mengikat anggota sebagai bagian dari kelompok dari beberapa aturan-aturan lama yang berlaku umum. Struktur norma yang diterapkan dalam kelompok masih bersifat pokok dan lama, seperti kewajiban anggota membayar iuran setiap bulan, kewajiban mengganti rugi apabila sapi yang dipelihara mati atau hilang dan kewajiban hadir pada setiap pertemuan kelompok sesuai kesepakatan.

\section{Persepsi terhadap kedudukan seseorang}

Persepsi anggota terhadap kedudukan seseorang memiliki skor 4,43, berada pada kategori sangat baik, berdasarkan "Kemampuan" dalam memimpin kelompok yang amanah, jujur, transparan, punya pengalaman dibidang tersebut dan dapat mengayomi anggota. Menurut (Ilham dan Yusdja 2004) pemimpin dapat dikatakan sebagai pintu masuk program pemberdayaan, sebagai penghubung antara kelompok dengan orang luar, dan sebagai jembatan masuknya informasi-informasi penting.

Kondisi dilapangan menunjukkan syarat menjadi ketua kelompok tidak harus memiliki pendidikan yang tinggi, $60 \%$ alasan pemilihan ketua kelompok 
berdasarkan status sosial dan memiliki kemampuan permodalan dan finansial. Sebagian petani memilih ketua berdasarkan kemampuan yang dimiliki, jenjang pendidikan yang ditempuh tidak bisa dijadikan kriteria seseorang memiliki kedudukan yang baik. Kedudukan ketua kelompok mayoritas memiliki pengalaman beternak sapi (sapi yang dimiliki secara pribadi), kepemilikan kebun kelapa sawit yang luas, kemampuan modal finansial yang memadai, kemampuan mengayomi anggota, kepedulian dan dipandang sebagai individu yang kreatif untuk menempati kedudukan sebagai ketua. Sementara itu sebagian anggota memilih ketua berdasarkan sifat jujur, ramah, tegas, disiplin, perduli terhadap sesama, kreatif dan terkenal di masyarakat karena suka membantu orang lain yang dalam kesulitan. Penunjukaan sebagai ketua juga berdasarkan kepemilikan ternak sapi terbanyak serta memiliki kemampuan finansial lebih baik sehingga layak menduduki jabatan sebagai ketua kelompok.

\section{Pengaruh norma terhadap aktivitas dan pencapaian tujuan kelembagaan}

Rata-rata skor indikator pengaruh norma terhadap aktivitas dan pencapaian tujuan kelompok adalah 4,25 termasuk kategori sangat baik, menunjukkan pengaruh norma yang ada mendukung dan memperlancar aktivitas sehari-hari, norma dianggap sebagai pemberi arah agar tujuan kelompok dapat tercapai secara efisien dan efektif. Modal sosial yang memiliki tingkat persepsi yang tinggi bagi petani adalah norma sosial, yaitu kegiatan saling tolong menolong antar petani (Ernanda et al. 2019).

Namun demikian terdapat kelompok yang memiliki anggota yang tidak peduli terhadap tanggungjawab dalam kelompok sehingga seluruh kegiatan pengelolaan SISKA dijalankan oleh ketua, sehingga tujuan yang sudah disepakati tidak tercapai.

\section{Pengaruh sentiment kekerabatan, pertemanan terhadap kelembagaan kelompok}

Mayoritas petani memberikan jawaban yang berada pada kategori sangat baik, dengan rata-rata skor 4,62. Pengaruh kekerabatan, pertemanan terhadap aktivitas sehari-hari dan pencapaian tujuan kelompok cenderung "mendukung dan memperlancar", seperti aturan mengenai pelaksanaan pemeliharaan ternak dan pengadaan pakan. Adanya aturan-aturan ini juga mempermudah dan memperjelas pembagian tugas mencari pelepah kelapa sawit, mencacah pelepah, pemberian pakan, pengolahan pupuk, sampai penjualan ternak. Sistem arisan yang dilakukan oleh sekelompok orang yang memiliki hubungan pertemanan, tetangga atau kekerabatan merupakan sebuah contoh yang jelas tentang bagaimana pentingnya arti kepercayaan (Syahra, 2003).

Sebagian besar anggota memiliki latarbelakang sebagai transmigran yang berasal dari desa yang sama. Hubungan personal yang saling mengenal 
menimbulkan sikap toleransi sehingga komunikasi terjalin dengan baik dan pengambilan keputusan dikelompok mudah dilakukan.

\section{Persepsi secara umum terhadap sistem reward dan punishment}

Persepsi terhadap sistem reward dan punishment berada pada kategori baik dengan skor 3,90, memandang penghargaan dan sanksi membuat anggota lebih disiplin dan termotivasi untuk meningkatkan kinerja. Mayoritas petani sangat setuju dengan sistem reward dan punishment dikelompok, sebagai bentuk apresiasi atas kinerja dan adanya sanksi akan membuat anggota kelompok lebih disiplin mentaati peraturan. Terdapat petani yang kurang setuju dengan sistem ini, karena akan menimbulkan dampak negatif terhadap hubungan social dalam kelompok, berupa kecemburuan antar anggota, adanya gap, dan timbulnya persaingan sesama anggota.

\section{Persepsi Terhadap Perilaku Dalam Kelompoktani}

Menurut Mardikanto (2009) perubahan perilaku lebih kekal dengan adanya pembelajaran ketimbang perubahan perilaku melalui paksaan, bujukan, aturan maupu ancaman. Selanjutnya nilai dan norma pada akhirnya melahirkan kepribadian, yaitu organisasi sikap-sikap yang dimiliki seseorang sebagi latar belakang terhadap perilaku, sehingga melahirkan kebiasaan. Kepribadian merupakan terminal akhir yang dihasilkan dari proses biologis, psikologis, dan sosiologis sekaligus. Secara keseluruhan indicator perilaku berada pada kategori baik dengan skor 3,75.

\section{Iklim utama dalam kelembagaan kelompoktani}

Menurut Syahyuti (2003) untuk identifikasi perilaku dalam kelompok dapat dilihat dari iklim utama dalam kelembagaan, apakah berlandaskan demokratis atau otoriter dari pihak yang lebih berkuasa. Persepsi petani terhadap iklim utama dalam kelompok sangat baik dengan skor 4,43, menunjukkan suasana demokratis, yakni pengambilan keputusan secara musyawarah dan mufakat, setiap anggota memiliki hak suara yang sama pada pemilihan ketua beserta perangkat serta dalam penetapan iuran bulanan.

\section{Faktor yang mempengaruhi perilaku tiap posisi dalam kelompoktani}

Berdasarkan jawaban petani dengan skor 3,63, faktor yang mempengaruhi perilaku tiap posisi dalam KT ialah "pengalaman", anggota kelompok memiliki pandangan bahwa seseorang yang memiliki pengalaman dalam usaha tani, memelihara ternak sapi dan mengolah limbah dianggap sebagai faktor yang mempengaruhi posisinya didalam kelompok. Menurut Manyamsari dan Mujiburrahmad (2014) petani yang memiliki pengalaman yang tinggi biasanya akan lebih dewasa dalam menghadapi berbagai persoalan 
dalam usaha tani. Selanjutnya penelitian Edwina dan Maharani (2014) menunjukkan lamanya berusahatani mencerminkan ketrampilan dalam mengelola usahatani, dengan pengalaman yang cukup petani lebih mampu dan matang mempertimbangkan setiap langkah keputusan baik dalam kegiatan usahatani maupun pemasaran hasil.

Tingkat pendidikan tidak menjadi faktor utama yang mempengaruhi tiap posisi dalam kelompok, rata-rata pendidikan terakhir ketua adalah SLTA bahkan ada yang tamat SD. Hasil penelitian Cepriadi dan Yulida (2012) menunjukkan meskipun pendidikan petani rendah tetapi pengalaman berusahatani akan membantu keberhasilannya karena dengan semakin tinggi pengalaman berusahatani maka mereka sudah terbiasa untuk menghadapi resiko dan mengetahui cara mengatasi masalah jika mengalami kesulitan dalam usahataninya.

\section{Sumber kekuatan yang menentukan perilaku kerja sehari-hari}

Hasil penelitian Mulyadi (2011) menunjukkan bahwa kearifan lokal berpengaruh positif dan signifikan terhadap tingginya perilaku berwawasan lingkungan petani dalam mengelola lahan pertanian. Sumber kekuatan yang menentukan perilaku kerja sehari-hari memiliki skor 3,66 tergolong baik menunjukan bersumber kekuatan berasal dari "kearifan setempat". Rata-rata jawaban petani menunjukkan dalam memelihara ternak, kearifan setempat menjadi sumber dan acuan. Contohnya aktivitas memelihara sapi dan mengolah limbah dilakukan setelah anggota selesai melakukan pekerjaan utama sebagai buruh di kebun sawit, aktivitas beternak merupakan pekerjaan sampingan untuk menghasilkan tabungan. Perilaku anggota yang berkaitan dengan intensitas pertemuan kelompok juga ditentukan oleh kebiasaan setempat dan rasa persaudaraan. Hal senada disampaikan oleh Rahmadi dan Santoso (2016) yang menyatakan dengan modal social, petani mampu menjalankan alternatif pendapatan lain diluar aktifitas bertani.

\section{Syarat khusus yang ditetapkan untuk menduduki jabatan pimpinan}

Peran pemimpin kelompok menurut (Mutmainah dan Sumardjo 2014) meliputi kemampuan pemimpin dalam memberikan arahan dan tuntunan bagi anggota kelompoknya, mampu memfasilitasi agar tercapai tujuan, mampu mendinamiskan para anggota untuk aktif, dan mampu dalam menampung aspirasi anggota kelompoknya. Syarat khusus yang ditetapkan untuk menduduki jabatan pimpinan berada pada kategori baik dengan skor 3,72, yaitu "ada 4-5 syarat",meliputi visi, sikap komunikatif, keteladanan, mengutamakan kepentingan orang lain dan memiliki sikap demokratis. Ratarata anggota menginginkan seorang pimpinan(ketua kelompok) dengan kriteria tersebut. 


\section{Kompetensi individu yang menjaddi pertimbangan dalam menduduki jabatan}

Kompetensi individu dipertimbangkan dalam menduduki jabatan dengan skor 3,93, berada pada kategori baik, menunjukkan "ada 3 kompetensi",yaitu (pendidikan, keterampilan, kematangan emosional). Menurut Yunasaf (2007) terdapat hubungan yang positif dan kuat antara kepemimpinan ketua kelompok dengan keefektifan kelompok mencapai tujuan. Pengalaman dan keterampilan merupakan kompetensi utama sedangkan kematangan emosional adalah kompetensi penunjang yang harus dimiliki oleh seseorang sebelum menduduki jabatan tertentu.

\section{Hal-hal yang dimiliki bersama}

Hal-hal yang dimiliki bersama yang mempengaruhi perilaku dalam kelompok termasuk kategori cukup baik, yaitu ada dua hal berupa kesamaan kepentingan dan tujuan.

\section{Hasil Uji Instrumen}

\section{Uji Validitas}

Uji validitas adalah uji yang digunakan untuk melihat pernyataan yang validitas dalam suatu pernyataan agar dapat menentukan sebuah variabel yang dapat digunakan dalam sebuah pengolahan data. Pengujian ini dilakukan dengan membandingkan nilai koefisien korelasi $R$ antara item peryataan dengan skor totalnya dengan cara membandingkan $\mathrm{R}$ hitung dengan $\mathrm{R}$ tabel. Pada variabel peran kelompoktani sebagai wahana kerjasama terdapat 2 indikator yang memiliki nilai $\mathrm{R}$ hitung $<\mathrm{R}$ tabel, dimana besar $\mathrm{R}$ tabel adalah 0,17 . Sedangkan pada aspek kelembagaan dalam sub variabel norma terdapat 1 indikator yang nilai $\mathrm{R}$ hitung $<\mathrm{R}$ tabel.

\section{Uji Reliabilitas}

Uji Reliabilitas dipergunakan sebagai alat ukur kuisioner yang digunakan sebagai indikator dari variabel. Pengujian reliabilitas dilakukan dengan menghitung nilai Cronbach's Alpha, dan apabila nilai Cronbach's Alpha lebih besar dari 0,61 maka alat ukur yang dipergunakan dalam penelitian ini tandanya reliabel atau dapat dipercaya. Hasil uji reliabilitas dapat dilihat pada Tabel 4. 
Tabel 4 Hasil Uji Reliabilitas Peran Kelompoktani Dan Aspek Kelembagaan

\begin{tabular}{cccl}
\hline Variabel & $\begin{array}{c}\text { Cronbach's } \\
\text { Alpha }\end{array}$ & $\begin{array}{c}\text { Nilai } \\
\text { Kritis }\end{array}$ & Kesimpulan \\
\hline $\begin{array}{c}\text { Peran } \\
\text { kelompoktani }\end{array}$ & 0,728 & 0,61 & Reliabel \\
\hline $\begin{array}{c}\text { Aspek } \\
\text { kelembagaan }\end{array}$ & 0,739 & 0,61 & Reliabel \\
\hline
\end{tabular}

\section{Hubungan Peran Kelompoktani dengan Aspek Kelembagaan}

Korelasi yang terjadi antara sub variabel nilai dan perilaku dengan variabel peran kelompoktani sebagai kelas belajar searah kuat karena nilai koefisien korelasi > rs tabel yakni berada pada rentang 0,41-0,70. Nilai rs antara sub variabel kelas belajar dengan sub variabel nilai ialah 0,580 dan perilaku 0,483 . Sementara korelasi sub variabel norma dengan sub variabel kelas belajar merupakan korelasi searah lemah dengan nilai rs 0,281.

Korelasi yang terjadi pada sub variabel nilai, norma dan perilaku terhadap peran kelompoktani sebagai unit produksi merupakan korelasi searah kuat. Nilai rs antara sub variabel unit produksi dengan sub variabel nilai ialah 0,645, norma 0,454 dan perilaku 0,521. Hal ini memperlihatkan bahwa nilai, norma dan perilaku yang diterapkan kelompoktani mempengaruhi, mendorong dan meningkatkan kelas belajar yang mendukung tingkat pengetahuan petani serta unit produksi yang dihasilkan juga akan semakin baik. Korelasi yang terjadi pada sub variabel nilai, norma dan perilaku terhadap peran kelompoktani sebagai wahana kerjasama merupakan korelasi berlawanan lemah. Nilai rs antara sub variabel wahana kerjasama dengan sub variabel nilai $-0,337$, norma $-0,222$ dan perilaku $-0,208$. dapat dilihat pada Tabel 5 .

\section{Tabel 5. Hubungan Aspek Kelembagaan Dan Peran Kelompoktani}

\begin{tabular}{|c|c|c|c|c|c|}
\hline & & & Nilai(X1.1) & $\begin{array}{c}\text { Norma } \\
(X 1.2)\end{array}$ & Perilaku (X1.3) \\
\hline \multirow{6}{*}{$\begin{array}{c}\text { Peran } \\
\text { Kelompoktani } \\
(\mathrm{Y})\end{array}$} & \multirow{3}{*}{$\begin{array}{c}\text { KelasBelaja } \\
\mathrm{r} \\
(\mathrm{Y} 1)\end{array}$} & $\begin{array}{l}\text { Correlation } \\
\text { Coefficient }\end{array}$ & $.580^{* *}$ & $.281^{* *}$ & $.483^{* *}$ \\
\hline & & Sig. (2-tailed) & .000 & .002 & .000 \\
\hline & & $\mathrm{N}$ & 125 & 125 & 125 \\
\hline & \multirow{3}{*}{$\begin{array}{l}\text { Unit } \\
\text { Produksi } \\
\text { (Y2) }\end{array}$} & $\begin{array}{l}\text { Correlation } \\
\text { Coefficient }\end{array}$ & $.645^{* *}$ & $.454^{* *}$ & $.521^{* *}$ \\
\hline & & Sig. (2-tailed) & .000 & .000 & .000 \\
\hline & & $\mathrm{N}$ & 125 & 125 & 125 \\
\hline
\end{tabular}




\begin{tabular}{cllcc}
\hline & Correlation & $-.337^{* *}$ & $-.222^{*}$ & $-.208^{*}$ \\
$\begin{array}{c}\text { Wahana } \\
\text { Kerjasama }\end{array}$ & Coefficient & & & \\
(Y3) & Sig. (2-tailed) & .000 & .013 & .020 \\
& $\mathrm{~N}$ & 125 & 125 & 125 \\
\hline
\end{tabular}

**. Correlation is significant at the 0.01 level (2-tailed).

*. Correlation is significant at the 0.05 level (2-tailed).

\section{SIMPULAN DAN SARAN}

\section{Simpulan}

Peran kelompoktani sebagai kelas belajar "cukup baik" dilihat dari hubungan dan kerjasama sesama anggota dan suasana belajar, namun peran dalam penyusunan rencana kurang baik, dan peran sebagai kelas belajar tidak baik. Peran sebagai unit produksi tergolong "baik", menunjukkan pola SISKA menguntungkan, dilihat dari pengembangan usaha seperti pengolahan limbah menjadi pupuk. Peran sebagai wahana kerjasama termasuk kategori baik, petani saling percaya didukung kecocokan dari ikatan pertemanan, persaudaraan dan latar belakang kesukuan, meskipun kegiatan pemasaran hasil dalam kelompok tergolong kurang baik.

Persepsi petani terhadap nilai yang berkembang dalam kelompok "sangat baik" terutama persepsi terhadap waktu dan hubungan sesama; persepsi terhadap norma yang berlaku termasuk "baik", didukung sistem norma yang diterapkan secara umum berlandaskan kearifan setempat dan agama.; perilaku dalam kelompok tergolong "baik" dilihat dari iklim demokratis, yakni pengambilan keputusan secara musyawarah dan mufakat.

Korelasi pada sub variabel nilai, norma dan perilaku terhadap peran kelompoktani sebagai unit produksi merupakan korelasi searah kuat, menunjukkan nilai, norma dan perilaku mempengaruhi, mendorong dan meningkatkan peran kelompok sebagai kelas belajar yang mendukung tingkat pengetahuan petani serta peran sebagai unit produksi.

\section{Saran}

Peran penyuluh dan Dinas Peternakan dalam menfasilitasi sarana belajar, pendampingan dalam penyusunan rencana kelompok dan pemasaran hasil perlu ditingkatkan untuk mengoptimalkan peran kelompoktani. 


\section{DAFTAR PUSTAKA}

Akdon, Hadi, S. 2005. Aplikasi Statiska Dan Metode Penelitian Untuk Administrasi dan Manajemen. Bandung: Dewa Ruchi.

Cepriadi, Yulida R. 2012. Persepsi Petani Terhadap Usahatani Lahan Pekarangan Studi Kasus Usahatani Lahan Pekarangan Di Kecamatan Kerinci Kabupaten Pelalawan. Indonesian Journal of Agricultural Economics (IJAE). 3 (2): 177-194

Edwina S, Maharani E. 2014. Kajian Keragaan Karakteristik Dan Tingkat Pengetahuan Petani Tentang Sistem Integrasi Sapi Dan Kelapa Sawit (SISKA) Di Kecamatan Pangkalan Lesung, Kabupaten Pelalawan. Jurnal Sosial Ekonomi Pertanian Dan Agribisnis (SEPA). 11 (1): 110 - 117

Ernanda R, Burhanuddin, Purwono J, 2019. Karakteristik Modal Sosial Petani Cabai Kopay Di Kota Payakumbuh. Jurnal Agrisep. 18(1):41-52.

Guntoro B, Wahyudi, Sulastri E. 2014. Farmers' Perception to The Role of

Extension Workers on Kaligesing Goat Farm Management in

Kaligesing, Purworejo. Jurnal Animal Production 16(3):202-209.

Harjoyo F X. 2009. Hubungan Antara Kompensasi Dan Kecerdasan Emosional

Dengan Komitmen Organisasional Pegawai Badan Pemeriksa Keuangan (GPK) Jakarta. Jakarta:UI Thesis.

Hermanto, Dewa K S Swastika. 2011. Penguatan Kelompok Tani: Langkah Awal Peningkatan Kesejahteraan Petani. Analisis Kebijakan Pertanian. 9(4):371-390.

Ilham N. Saliem H P. 2011. Kelayakan Finansial Sistem Integrasi Sawit-Sapi Melalui Program Kredit Usaha Pembibitan Sapi. Analisis Kebijakan Pertanian. 9(4):349-369.

Kartasapoetra A G. 1994. Teknologi Penyuluhan Pertanian. Jakarta: Bumi Aksara. Manyamsari I, Mujiburrahmad. 2014. Karakteristik Petani Dan Hubungannya Dengan Kompetensi Petani Lahan Sempit (Kasus : Di Desa Sinar Sari Kecamatan Dramaga Kab. Bogor Jawa Barat). Jurnal Agrisep. 15(2): 5874.

Mardikanto T. 2009. Sistem Penyuluhan Pertanian. Solo: UNS Press.

Mutmainah R, Sumardjo. 2014. Peran Kepemimpinan Kelompok Tani Dan Efektifvitas Pemberdayaan Petani. Jurnal Sosiologi Pedesaan. 02(03):182199.

Mulyadi. 2011. Pengaruh Kearifan Lokal, Locus Of Control, Dan Motivasi Terhadap Perilaku Berwawasan Lingkungan Petani Dalam Mengelola Lahan Pertanian Di Kabupaten Soppeng. Jurnal Manusia Dan Lingkungan. 18 (1): 60 - 67.

Ramadoan S, Muljono P, Pulungan I. 2013. Peran PKSM Dalam Meningkatkan Fungsi Kelompok Tani Dan Partisipasi Masyarakat Di Kabupaten Bima NTB. Jurnal Penelitian Sosial Dan Ekonomi Kehutanan. 10(3):199210. 
Rintar. 2011. Hubungan Kualitas Jasa Terhadap Kepuasan Konsumen Pada Lembaga Pendidikan Kejuruan. Jurnal Dinamika Manajemen. 2(1):40-47. Rahmadi P Z, Santoso B. 2016. Modal Sosial Petani Sawah Berlahan Sempit dalam Pemenuhan Nafkah Rumah Tangga. Jurnal Analisa Sosiologi. 5(1): 62-73.

Sugiyono. 2017. Metode Penelitian Bisnis. Bandung: Alfabeta.

Syahra, Rusdi. 2003. Modal Sosial Konsep dan Aplikasi. Jurnal Masyarakat dan Budaya. 5(1): 1 - 22.

Syahyuti. 2003. Bedah Konsep Kelembagaan: Strategi Pengembangan Dan Penerapannya Dalam Penelitian Pertanian. Bogor: Puslitbang Sosek Pertanian Puslitbangtan.

Trisnanto T B, Fitriani, Fatih C. 2017. Membangun Modal Sosial Pada Gabungan Kelompok Tani. Jurnal Masyarakat, Kebudayaan Dan Politik. 30(1):59-67.

Wastika C Y, Hariadi S S, Subejo. 2014. Peran Kelompok Tani Dalam Penerapan SRI (System Of Rice Intensification) Di Kecamatan Kalikajar Kabupaten Wonosobo. Jurnal Agro Ekonomi. 24(1):84-93.

Yunasaf U. 2007. Kepemimpinan Ketua Kelompok Dan Hubungannya Dengan Keefektifan Kelompok (Kasus Pada Kelompoktani Ternak Sapi Perah Di Wilayah Kerja Koperasi Serba Usaha Tandangsari Sumedang). Jurnal Ilmu Ternak. 7(2):179-185. 